\title{
The Effect of Potassium Deficiency on Growth and Physiology in Sweetpotato [Ipomoea batatas (L.) Lam.] during Early Growth
}

\author{
Ming Liu', Aijun Zhang, Xiaoguang Chen, Rong Jin, Hongmin Li', \\ and Zhonghou Tang ${ }^{2}$ \\ Xuzhou Sweetpotato Research Center, Jiangsu, China; and Key Laboratory \\ of Sweetpotato Biology and Genetic Breeding, Ministry of Agriculture, \\ Xuzhou, Jiangsu Province, 221121, China
}

Additional index words. $\mathrm{K}^{+}$deficiency stress, dry weight, root activity, photosynthesis, chlorophyll fluorescence parameters

\begin{abstract}
Potassium $\left(\mathrm{K}^{+}\right)$is an essential nutrient element for the growth and development of sweetpotato [Ipomoea batatas (L.) Lam.]. To investigate growth and physiological responses to $\mathrm{K}^{+}$deficiency during early growth stage of sweetpotato, two representative cultivars with different tolerance to $K^{+}$deficiency were chosen. The seedlings of 'Xushu 32' (tolerance to $\mathrm{K}^{+}$deficiency) and 'Ningzishu 1' (sensitive to $\mathrm{K}^{+}$deficiency) were cultured in three different $\mathrm{K}^{+}$concentrations $\left(\mathrm{K0:0} \mathbf{~ m m o l} \cdot \mathrm{L}^{-1} \mathrm{~K}^{+} ; \mathbf{K 1 :} \mathbf{5} \mathrm{mmol} \cdot \mathrm{L}^{-1} \mathrm{~K}^{+}\right.$; and $\mathrm{K} 2$ : $20 \mathrm{mmol} \cdot \mathrm{L}^{-1} \mathrm{~K}^{+}$, the control) of nutrient solution. Results showed that the extreme $\mathrm{K}^{+}$deficiency $(\mathrm{K} 0)$ significantly reduced the total dry weight, leaf number, root length, and chlorophyll content (CCI) compared with K2. However, the growth traits of 'Xushu 32' were less suppressed than those of 'Ningzishu 1'. The net photosynthetic rate $\left(P_{n}\right)$, stomatal conductance $\left(g_{S}\right)$, and transpiration rate $\left(T_{r}\right)$ of 'Ningzishu 1 ' were significantly decreased in $\mathrm{KO}$ and $\mathrm{K1}\left(\mathrm{low} \mathrm{K}^{+}\right)$, whereas 'Xushu 32' showed no significant change in $\mathrm{K} 1$ treatment. Increasing minimal fluorensence $\left(F_{0}\right)$ of 'Ningzishu 1 ' comes with decreased maximum quantum efficiency of photosystem II (PSII) photochemistry $\left(F_{\mathrm{v}} / F_{\mathrm{m}}\right)$ and photochemical quenching $\left(q_{\mathrm{P}}\right)$ at K0 treatment. However, all the chlorophyll fluorescence parameters in 'Xushu 32' were nonsignificantly changed by $\mathrm{K}^{+}$deficiency (K0 and K1). These results suggest that ' $X u s h u$ 32' could maintain a better growth state to adapt to $\mathrm{K}^{+}$deficiency stress, which may be mainly because of a lighter affected photosynthesis and a less damaged PSII reaction center.
\end{abstract}

Potassium $\left(\mathrm{K}^{+}\right)$is an essential macronutrient required for crop growth and development, which is known to modify abundant enzyme activations in different metabolic pathways and to regulate cell osmotic pressure and stomatal movements (Coskun et al., 2014; George et al., 2002; Marschner, 2011; Singh et al., 2003). It has been proved that appropriate $\mathrm{K}^{+}$additions can increase crop yields and improve crop quality (Bednarz and Oosterhuis, 1999; Constantin et al., 1977; He et al., 2004). Sweetpotato [Ipomoea batatas (L.) Lam.] is an important human food, animal feed, and industrial raw material,

\footnotetext{
Received for publication 6 Apr. 2017. Accepted for publication 18 May 2017.

This study was financially supported by the Natural Science Foundation of Jiangsu Province (BK20151162), the National Natural Science Foundation of China (31461143017-2), and the Ministry of Agriculture of the People's Republic of China with funds earmarked for the China Agriculture Research System (CARS-11-B-13) and the Special Fund for Agro-scientific Research in the Public Interest (201403039).

${ }^{1}$ Contributed equally.

${ }^{2}$ Corresponding author. E-mail: zhonghoutang@ sina.com.
}

which is grown in more than 100 countries and mainly produced in China (FAO, 2011; Jin, 2012). Sweetpotato is a typical "Kfavoring" crop (Tang et al., 2014); its growth as well as developmental and physiological responses can be affected by conditions of $\mathrm{K}^{+}$deficiency (Gajanayake et al., 2014). With an increase in arable soil facing serious $\mathrm{K}^{+}$deficiency (Hijmans et al., 2001), it has become a key factor affecting the productivity and quality of sweetpotato (Karam et al., 2009; Yang et al., 2003).

Crops have genotype differences in tolerance to stress. Tolerant cultivars had high absorption efficiency and low effect on growth and production in $\mathrm{K}^{+}$deficiency stress (Wang et al., 2012; Zhao et al., 2016). Sweetpotato has been known to exhibit genotypic variation in $\mathrm{K}^{+}$uptake and utilization efficiency (George et al., 2002). Exploring its physiological characters of tolerance to $\mathrm{K}^{+}$ deficiency can provide a basis for increasing the fertilizer utilization and improving the yield in K-deficiency soil. Previous studies have shown that $\mathrm{K}^{+}$deprivation can induce changes in the relative growth of roots, nodules, and shoots in higher plants (HøghJensen, 2003; Wang and $\mathrm{Wu}, 2013)$. In sweetpotato, its root dry matter yield and biomass productivity significantly affected by $\mathrm{K}^{+}$supplied; intraspecific variation among genotypes also existed (Wang et al., 2015a). The negative impact on the $T_{\mathrm{r}}, P_{\mathrm{n}}$, and $g_{\mathrm{S}}$ in $\mathrm{K}^{+}$deficiency condition is well documented in other crops (Kanai et al., 2011; Reddy and Zhao, 2005). Potassium deficiency also affects foliar chlorophyll synthesis and stability, and modifies the chloroplast ultrastructure of leaves (Zhao et al., 2001). Such responses to $\mathrm{K}^{+}$deficiency may also exist in sweetpotato.

Chlorophyll fluorescence kinetics is an important way to detect and analyze plant photosynthetic function, and this method has been gradually applied to studies on plant nutrition stress; e.g., for nitrogen $(\mathrm{N})$ (Bürling et al., 2011), magnesium (Mohotti and Lawlor, 2002), and phosphorus (Yang et al., 2004). However, chlorophyll fluorescence kinetics has been rarely reported for sweetpotato in conditions of $\mathrm{K}^{+}$deficiency. Prior studies have reported that $\mathrm{K}^{+}$deficiency affects plant growth and development processes, particularly when it occurs during the early growth stage of plant establishment (Karam et al., 2009; Ning et al., 2013; Yang et al., 2003; Zhao et al., 2001). As for sweetpotato, the root differentiation process is basically completed in the early growth stage (about $30 \mathrm{~d}$ after the cutting being transplanted), and the growth status of root is closely related to the effective sweetpotato number, which has a decisive effect on the final root yield (Wang et al., 2005). It has been proved that, when $\mathrm{K}^{+}$deficiency occurs at this stage, the number of branches and leaves, the biomass, and leaf area per plant are significantly decreased, resulting in the reduction of the yield and quality (Ning et al., 2013). Therefore, it is necessary to research the information regarding the growth and physiological responses of sweetpotato to $\mathrm{K}^{+}$ deficiency in the early growth stage, and the possible mechanisms would provide a basis for further exploration on resistance cultivation and molecular breeding for low $\mathrm{K}^{+}$in sweetpotato.

This study presents a comparison between two different low-K-tolerant varieties in terms of their differential physiological responses to $\mathrm{K}^{+}$deficiency stress. The aims were to investigate the effects of $\mathrm{K}^{+}$deficiency during early growth stage on sweetpotato growth, physiology, photosynthetic, and chlorophyll fluorescence parameters, and to make a preliminary study of the possible mechanism underpinning sweetpotato tolerance to $\mathrm{K}^{+}$deficiency.

\section{Materials and Methods}

Plant materials. The two cultivars, 'Xushu 32' (tolerant to $\mathrm{K}^{+}$deficiency, short vine, dark green leaf, light yellow flesh, and good taste, bred by Xuzhou Sweetpotato Research Center, Jiangsu) and 'Ningzishu 1 ' (sensitive to $\mathrm{K}^{+}$deficiency, purple flesh, and good taste, bred by Jiangsu Academy of Agricultural Sciences) are widely cultivated in China. The two cultivars were screened 
from 31 materials according to their $\mathrm{K}^{+}$ utilization efficiencies and $\mathrm{K}^{+}$sensitivity index (relative root weight) (Tang et al., 2014). In the following field experiment, it has been proved that 'Xushu 32' has a higher total biomass productivity and root yield, as well as higher protective enzyme activities than those of 'Ningzishu 1', in $\mathrm{K}^{+}$deficiency condition (Tang et al., 2015).

In this experiment, sweetpotato seedlings with consistent growth were chosen to take the cuttings with a length of $20 \pm 0.5 \mathrm{~cm}$, a base stem diameter of $12-13 \mathrm{~mm}$, four leaves, and three internodes. The cuttings were cultured in water and placed in shadow. After $3 \mathrm{~d}$ of recovery, they were transplanted to a hydroponic system.

Growth conditions. The experiment was conducted from 13 July to 15 Aug. 2016 in the rainproof greenhouse of the Xuzhou Sweetpotato Research Center, Jiangsu Province, China. As shown in Fig. 1, the hydroponic system was mainly composed of PVC pipes, mini water pump, and nutrient solution container. The PVC pipes were the planting container, with a diameter of $110 \mathrm{~mm}$ and a length of $1.6 \mathrm{~m} ; 2 \mathrm{~cm}$ in diameter holes were equidistantly distributed (spacing $15 \mathrm{~cm}$, totally 15 holes) at the top. The nutrient solution flowed through the PVC pipes and circulated via water pump. The nutrient solution in the PVC pipes was at shallow depth, to ensure the nutrient solution circulation and adequate oxygen in the root domain. Single cutting fixed with foam collars in a planting basket was put into the hole, and a portion of the stem was immersed in the nutrient solution to promote rooting. Fifteen cuttings of the same variety were planted in one PVC pipe, and the three pipes on same floor were set as one replicate. The experiment was conducted using a randomized design with three replicates per treatment.

The nutrient solution was modified by using Hoagland's nutrient solution to contain $6.0 \mathrm{mmol} \cdot \mathrm{L}^{-1} \mathrm{CaCl}_{2}, 6.0 \mathrm{mmol} \cdot \mathrm{L}^{-1} \mathrm{NaNO}_{3}$, $1.0 \mathrm{mmol} \cdot \mathrm{L}^{-1} \mathrm{NH}_{4} \mathrm{H}_{2} \mathrm{PO}_{4}, 4.0 \mathrm{mmol} \cdot \mathrm{L}^{-1} \mathrm{MgSO}_{4}$, $0.2 \mathrm{mmol} \cdot \mathrm{L}^{-1} \mathrm{FeSO}_{4}, 0.26 \mathrm{mmol} \cdot \mathrm{L}^{-1} \mathrm{EDTA}$, $46 \mu \mathrm{mol} \cdot \mathrm{L}^{-1} \mathrm{H}_{3} \mathrm{BO}_{3}, 10 \mu \mathrm{mol} \cdot \mathrm{L}^{-1} \mathrm{MnSO}_{4}$, $0.76 \mu \mathrm{mol} \cdot \mathrm{L}^{-1} \mathrm{ZnSO}_{4}, 0.32 \mu \mathrm{mol} \cdot \mathrm{L}^{-1} \mathrm{CuSO}_{4}$, and $0.0162 \mu \mathrm{mol} \cdot \mathrm{L}^{-1}\left(\mathrm{NH}_{4}\right)_{6} \mathrm{Mo}_{7} \mathrm{O}_{24}$. Three levels of the $\mathrm{K}^{+}$treatment were set at $0 \mathrm{mmol} \cdot \mathrm{L}^{-1}(\mathrm{~K} 0), 5 \mathrm{mmol} \cdot \mathrm{L}^{-1}(\mathrm{~K} 1)$, and 20 $\mathrm{mmol} \cdot \mathrm{L}^{-1}$ (K2) (i.e., control) using $\mathrm{K}_{2} \mathrm{SO}_{4}$. The nutrient solution was renewed once a week.

Gas exchange and chlorophyll fluorescence measurement. Gas exchange and chlorophyll fluorescence parameters were measured using a portable photosynthesis system (LI-6400 XT, LI-COR, Inc., Lincoln, NE). The $P_{\mathrm{n}}, T_{\mathrm{r}}, g_{\mathrm{S}}$, and intercellular $\mathrm{CO}_{2}$ concentration $\left(C_{\mathrm{i}}\right)$ were measured on the upper, third fully-expanded leaves of the main stem at 9:30-11:30 AM 10, 17, 24, and $31 \mathrm{~d}$ after treatment (DAT). The chamber environment was controlled and set at a constant airflow rate of $500 \mu \mathrm{mol} \cdot \mathrm{s}^{-1}$, a leaf temperature of $28 \pm 0.5^{\circ} \mathrm{C}$, a $\mathrm{CO}_{2}$ concentration of $(400 \pm 5) \mu \mathrm{mol} \cdot \mathrm{mol}^{-1}$, and a photosynthetic photon flux density of $1000 \mu \mathrm{mol} \cdot \mathrm{m}^{-2} \cdot \mathrm{s}^{-1}$ provided by a red/blue light source. The chlorophyll fluorescence parameters were measured on the same leaves after keeping in the dark for $30 \mathrm{~min}$ on the $24 \mathrm{DAT}$, including $F_{0}$, the maximal fluorescence $\left(F_{\mathrm{m}}\right), F_{\mathrm{v}} / F_{\mathrm{m}}$, $q_{\mathrm{P}}$, and nonphotochemicalquenching $\left(q_{\mathrm{N}}\right)$. Three representative leaves were chosen to evaluate the parameters, and the means were used as the treatment values for each measurement.

Growth characteristics and root activity measurement. Plants were sampled at 10, 17, 24 , and 31 DAT. Three seedlings from each replicate were randomly collected to count their number of green leaves, and to measure their shoot and root lengths each time. Total leaf CCI was estimated on the same leaves using a portable chlorophyll meter (CCM200; Opti-Sciences, Tyngsboro, MA). Roots were cut from the same seedlings and washed with distilled water. Root activity was analyzed by the triphenyl tetrazolium chloride (TTC) method (Wang et al., 2006). In brief, $1.0 \mathrm{~g}$ fresh root was immersed in $10 \mathrm{~mL}$ of equally mixed solution of $0.4 \%$ TTC and phosphate buffer, and kept in the dark at $37^{\circ} \mathrm{C}$ for $2 \mathrm{~h}$. Subsequently, $2 \mathrm{~mL}$ of $1 \mathrm{~mol} \cdot \mathrm{L}^{-1}$ $\mathrm{H}_{2} \mathrm{SO}_{4}$ was added to stop the reaction with the root. The root was dried using filter paper and then extracted with ethyl acetate. The red extractant was transferred into the volumetric flask to reach $10 \mathrm{~mL}$ by adding ethyl acetate. The absorbance of the extract at $485 \mathrm{~nm}$ was recorded. Root activity was expressed as TTC reduction intensity. Root activity $=$ amount of TTC reduction $(\mu \mathrm{g}) /$ time $(\mathrm{h}) \times$ fresh root weight (g FW). At 31 DAT, three more plants were sampled and separated into shoot and root parts, which were oven-dried at $105^{\circ} \mathrm{C}$ for $30 \mathrm{~min}$ and then again at $80^{\circ} \mathrm{C}$ for $72 \mathrm{~h}$ to a constant weight.

Statistical analysis. All data were analyzed using the software program SPSS (SPSS Statistics v. 17.0), and the results were presented as the sample means $\pm \mathrm{SD}(n=3)$. Statistical analysis used analysis of variance followed by Turkey's test at a significance level of $P=0.05$.

\section{Results}

\section{Effects of $\mathrm{K}^{+}$deficiency on dry weight}

The total dry weight of 'Ningzishu 1' (sensitive to $\mathrm{K}^{+}$deficiency) significantly decreased in conditions of $\mathrm{K}^{+}$deficiency ( $\mathrm{K} 0$ and $\mathrm{K} 1$ levels) (Table 1) at $31.8 \%$ and $19.1 \%$ compared with the control (K2), respectively. But for 'Xushu 32' (tolerant to $\mathrm{K}^{+}$deficiency), the corresponding decrease of $\mathrm{K} 0$ and $\mathrm{K} 1$ was at $14.1 \%$ and $8.0 \%$, respectively, which were lower than those of 'Ningzishu 1'. The total dry weight of 'Ningzishu 1' was significantly lower than the corresponding values of 'Xushu 32' in $\mathrm{K} 0$ and $\mathrm{K} 1$, respectively, but showed no significant difference in the K2 level. The variations of shoot dry weight of the two varieties were similar to total dry weight, except for that there was no significant difference between the three $\mathrm{K}^{+}$ level treatments for 'Xushu 32'.

The root dry weight of $\mathrm{K} 2$ was significantly higher than that of $\mathrm{K} 0$ and $\mathrm{K} 1$ for 'Ningzishu 1'. As to 'Xushu 32', there was a slight decrease in root dry weight when the $\mathrm{K}^{+}$concentrations were reduced, but no significant difference was shown between the three $\mathrm{K}^{+}$levels. In each $\mathrm{K}^{+}$level, the root dry weight as well as the root/shoot ratio of 'Ningzishu 1' was significantly lower than that of 'Xushu 32'. The root/shoot ratio of 'Ningzishu 1' was significantly decreased in K0 condition, which was not shown in 'Xushu 32'. The K0 of 'Ningzishu 1' had the lowest values for all the trait responses.

\section{Effects of $\mathrm{K}^{+}$deficiency on seedling growth characteristics}

Number of expanded leaves. The $\mathrm{K}^{+} \mathrm{de}-$ ficiency caused a decrease in leaf number in the two cultivars (Fig. 2). In 'Xushu 32', the number of expanded leaves showed statistically significant differences mainly at 31 DAT. By contrast, the 'Ningzishu 1' has shown significant difference in $\mathrm{K} 0$ since day 10 by comparing with either K1 or K2. At 31

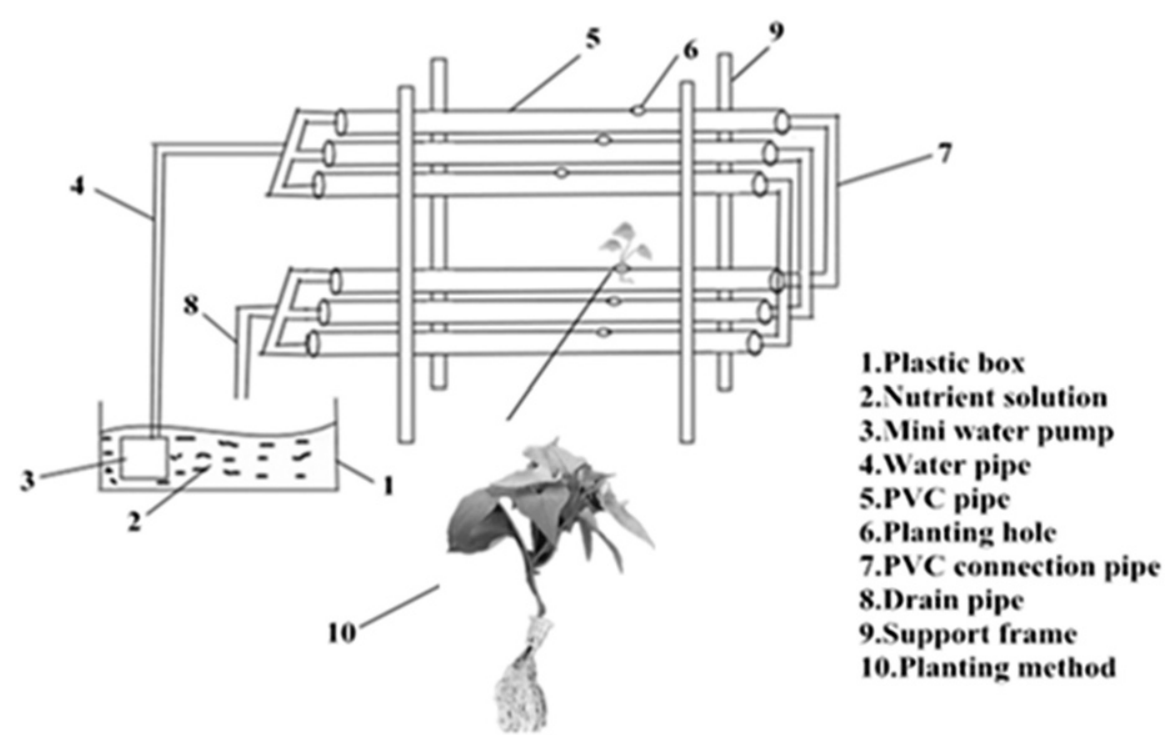

Fig. 1. Illustration of the cultivating device. 
Table 1. Effects of potassium deficiency on dry weight and root/shoot ratio of two sweetpotato varieties.

\begin{tabular}{|c|c|c|c|c|c|}
\hline \multirow{2}{*}{$\begin{array}{l}\text { Variety } \\
\text { Xushu } 32\end{array}$} & Treatment & Root dry weight (g/plant) & Shoot dry weight (g/plant) & Total dry weight (g/plant) & Root/shoot \\
\hline & K2 & $1.20 \pm 0.10 \mathrm{a}$ & $4.27 \pm 0.23 \mathrm{a}$ & $5.47 \pm 0.25 \mathrm{a}$ & $0.28 \pm 0.03 \mathrm{a}$ \\
\hline \multirow[t]{2}{*}{ Ningzishu 1} & K0 & $0.43 \pm 0.12 \mathrm{c}$ & $3.00 \pm 0.30 \mathrm{c}$ & $3.43 \pm 0.40 \mathrm{~d}$ & $0.14 \pm 0.03 \mathrm{c}$ \\
\hline & $\mathrm{K} 2$ & $0.87 \pm 0.06 \mathrm{~b}$ & $4.17 \pm 0.15 \mathrm{a}$ & $5.03 \pm 0.21 \mathrm{ab}$ & $0.21 \pm 0.01 \mathrm{ab}$ \\
\hline
\end{tabular}

K0: $0 \mathrm{mmol} \cdot \mathrm{L}^{-1} \mathrm{~K}^{+}$; K1: $5 \mathrm{mmol} \cdot \mathrm{L}^{-1} \mathrm{~K}^{+} ; \mathrm{K} 2: 20 \mathrm{mmol} \cdot \mathrm{L}^{-1} \mathrm{~K}^{+}$(control).

${ }^{\mathrm{z}}$ Means within same column followed by different letters $(\mathrm{a}, \mathrm{b}$, and $\mathrm{c})$ are significantly different between $\mathrm{K}$ treatments of the two genotypes $(P<0.05)$. Data are means $\pm \operatorname{SD}(n=3)$.

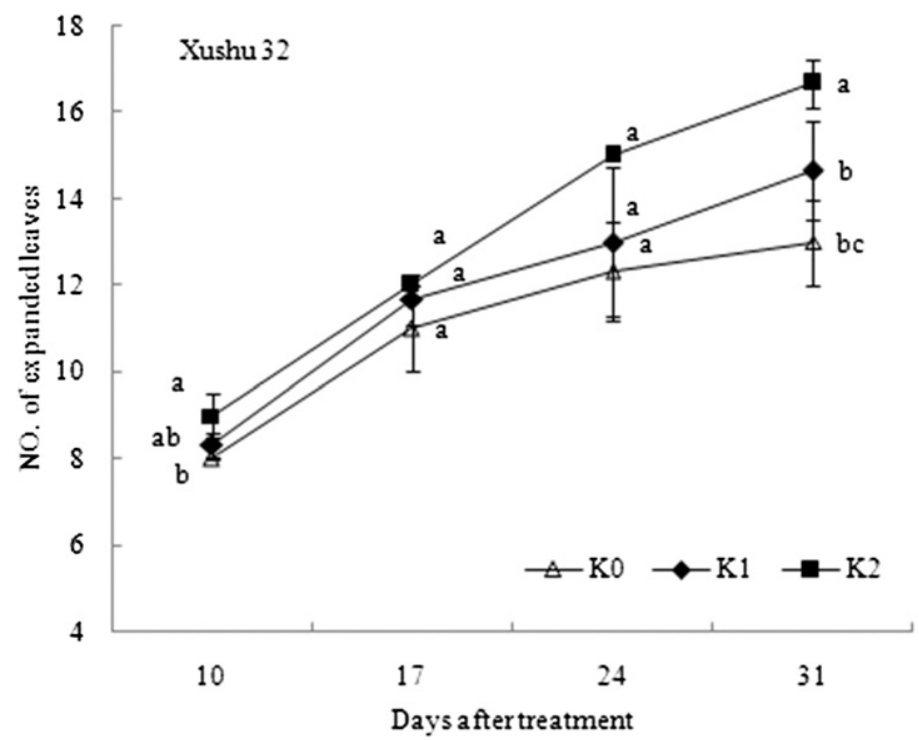

\section{Ningzishu 1}

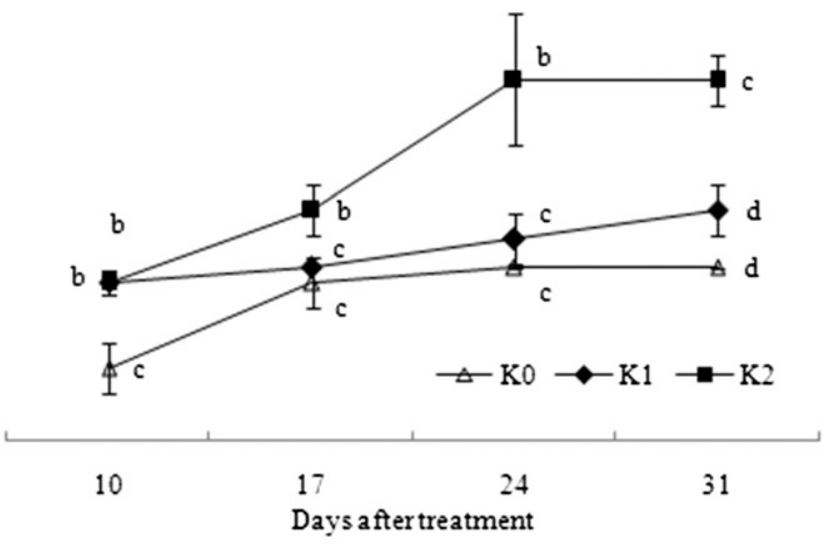

Fig. 2. Effects of potassium deficiency on the number of expanded leaves of two sweetpotato varieties. $\mathrm{K} 0: 0 \mathrm{mmol} \cdot \mathrm{L}^{-1} \mathrm{~K}^{+} ; \mathrm{K} 1: 5 \mathrm{mmol} \cdot \mathrm{L}^{-1} \mathrm{~K}+$; and $\mathrm{K} 2: 20 \mathrm{mmol} \cdot \mathrm{L}^{-1} \mathrm{~K}^{+}$(control). Data are means $\pm \mathrm{SD}(n=3)$. Treatments with different letters $(\mathrm{a}, \mathrm{b}$, and $\mathrm{c})$ are significantly different at $P<0.05$ level.

DAT, the decrease of $\mathrm{K} 0$ and $\mathrm{K} 1$ was at $35.1 \%$ and $24.3 \%$ compared with $\mathrm{K} 2$, respectively. For 'Xushu 32', the corresponding decreases were lower, at $22.0 \%$ and $12.0 \%$, respectively. On the other hand, the leafing rates of 'Ningzishu 1' were lower than those of 'Xushu 32', in each $\mathrm{K}^{+}$level condition.

Shoot length and root length. The shoot lengths of 'Xushu 32' were lower than that of 'Ningzishu 1', whereas the response in root lengths showed an opposite pattern (Figs. 3 and 4). Over the experimental period, the shoot lengths for 'Xushu 32' showed few differences among the treatment levels, whereas for 'Ningzishu 1', the shoot lengths were significantly reduced at $\mathrm{K}^{+}$deficiency conditions (i.e., $\mathrm{K} 0$ and $\mathrm{K} 1$ ). At $31 \mathrm{DAT}$, the shoot lengths of $\mathrm{K} 0$ and $\mathrm{K} 1$ in 'Xushu 32' had decreased by $8.4 \%$ and $5.9 \%$ compared with $\mathrm{K} 2$, respectively, whereas the corresponding decreases were significant at $20.7 \%$ and $13.4 \%$ for 'Ningzishu 1 '.

The stress of $\mathrm{K}^{+}$deficiency significantly reduced the root length of both sweetpotato cultivars. At 31 DAT, root length of 'Xushu $32^{\prime}$ in $\mathrm{K} 0$ and $\mathrm{K} 1$ treatment was $15.7 \%$ and $13.6 \%$ lower than that of K2, respectively. As for 'Ningzishu 1', the corresponding decreases were higher by $22.8 \%$ and $18.1 \%$, respectively.

Chlorophyll content. The $\mathrm{K}^{+}$deficiency caused decreases in CCI in the two cultivars (Fig. 5). Significant differences were evident among the $\mathrm{K} 0, \mathrm{~K} 1$, and $\mathrm{K} 2$ treatment levels only in 'Ningzishu 1' from 10 to 31 DAT. At 31 DAT, the CCI of K0 and K1 in 'Xushu 32' was $27.5 \%$ and $17.1 \%$ lower than that of $\mathrm{K} 2$, respectively; whereas the corresponding values of 'Ningzishu 1' had significantly decreased by $59.8 \%$ and $35.3 \%$. The CCI of the two varieties declined steadily from 10 to 31 DAT. Over this period, the CCI of K0, K1, and $\mathrm{K} 2$ in 'Xushu 32 ' decreased by $47.4 \%$, $44.9 \%$, and $43.3 \%$, respectively. However, in the case of 'Ningzishu 1', the corresponding decreases were more remarkable at $77.7 \%$, $70.3 \%$, and $60.0 \%$, respectively.

Effects of $\mathrm{K}^{+}$deficiency on root activity. Root activity variations are shown in Fig. 6. The $\mathrm{K}^{+}$deficiency decreased root activity in the two cultivars, but only 'Ningzishu 1' showed significant differences between $\mathrm{K} 0$ and $\mathrm{K} 2$ level from 24 to 31 DAT of the experiment. For 'Ningzishu 1', their root activity in the $\mathrm{K} 0$ and $\mathrm{K} 1$ conditions was reduced by $43.9 \%$ and $20.7 \%$ compared with that of K2, respectively. Moreover, the reduction of $\mathrm{K} 0$ and $\mathrm{K} 1$ in 'Ningzishu 1' was $54.7 \%$ and $40.8 \%$, respectively, from 10 to 31 DAT, whereas the corresponding reduction was $39.6 \%$ and $36.8 \%$, for 'Xushu 32 '.

\section{Effects of $\mathrm{K}^{+}$deficiency on leaf photosynthesis}

Net photosynthesis. The extreme $\mathrm{K}^{+} \mathrm{de}-$ ficiency (K0) caused significant decreases in
$P_{\mathrm{n}}$ of the two cultivars from 10 to 31 DAT (Fig. 7). At 31 DAT, the $P_{\mathrm{n}}$ of $\mathrm{K} 0$ and $\mathrm{K} 1$ in 'Xushu 32 ' decreased by $44.6 \%$ and $29.9 \%$ compared with $\mathrm{K} 2$, respectively; the corresponding decreases of 'Ningzishu 1' were $59.7 \%$ and $30.8 \%$. At 10 DAT, the $P_{\mathrm{n}}$ of each $\mathrm{K}^{+}$level in 'Ningzishu 1' was higher than that of 'Xushu 32', but was lower than that of 'Xushu 32' at 31 DAT. The $P_{\mathrm{n}}$ of the two sweetpotato varieties decreased gradually from 10 to 31 DAT. By 31 DAT, relative to 10 DAT, the decline in their $P_{\mathrm{n}}$ was $54.0 \%$, $51.5 \%$, and $45.0 \%$ for $\mathrm{K} 0, \mathrm{~K} 1$, and $\mathrm{K} 2$ in 'Xushu 32', respectively, which was obviously lower than the corresponding decline of $80.0 \%, 68.6 \%$, and $61.1 \%$ in 'Ningzishu 1', respectively.

Stomatal conductance. The changes in $g_{\mathrm{S}}$ in the two cultivars are shown in Fig. 8. A lower $\mathrm{K}^{+}$concentration applied revealed a lower $g_{\mathrm{S}}$ response, as significantly shown from 24 to 31 DAT for 'Ningzishu 1'. For 'Xushu 32', the corresponding decreases were also shown but much lower, and there was no significant difference between $\mathrm{K} 0$ and $\mathrm{K} 1$. The $g_{\mathrm{S}}$ of 'Xushu 32' decreased from 10 to $31 \mathrm{DAT}$, amounting to $43.0 \%, 50.3 \%$, and $49.7 \%$ for $K 0, K 1$, and $K 2$, respectively. However, in the case of 'Ningzishu 1', the corresponding $g_{\mathrm{S}}$ values were reduced by $90.2 \%, 84.3 \%$, and $77.5 \%$, respectively. Furthermore, the $g_{\mathrm{S}}$ of three treatment levels in seedlings of 'Ningzishu 1' was greater than 

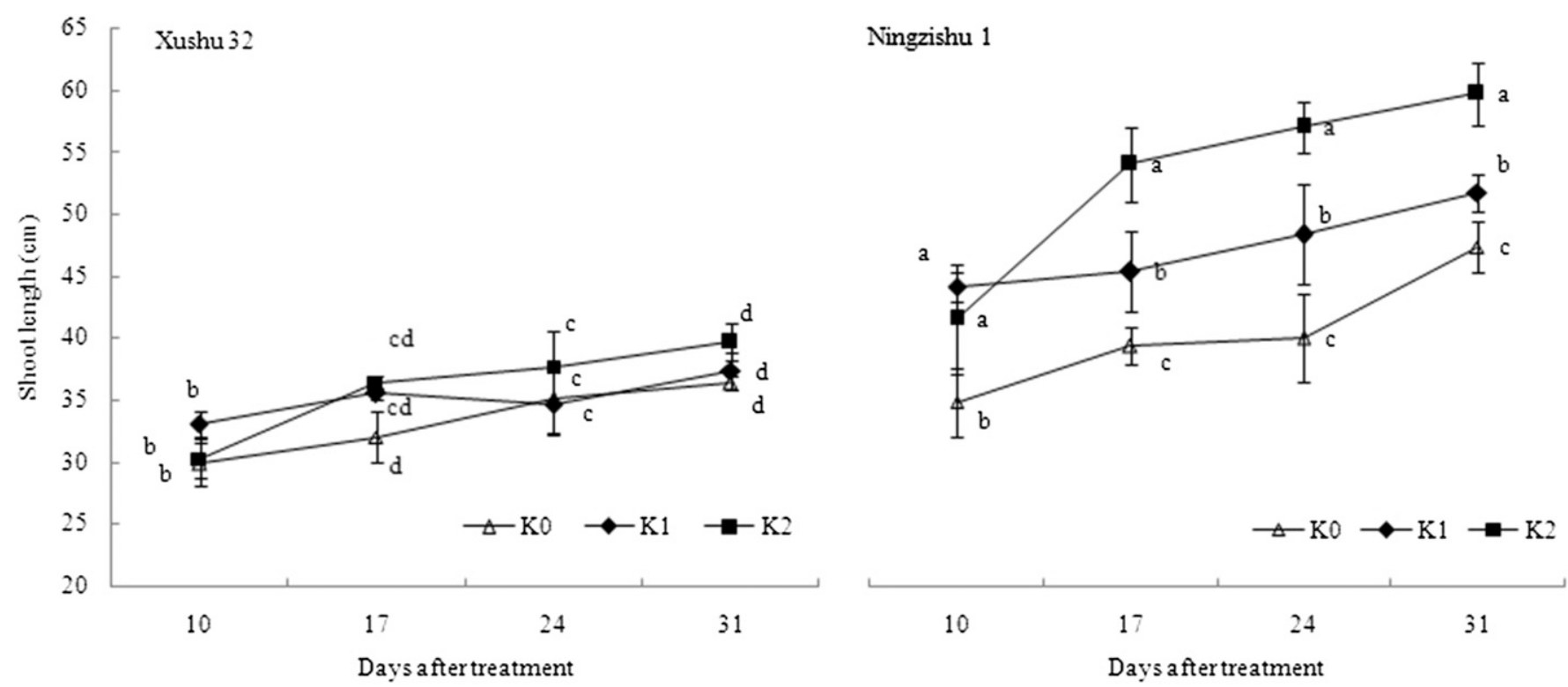

Fig. 3. Effects of potassium deficiency on the shoot length of two sweetpotato varieties. $\mathrm{K} 0: 0 \mathrm{mmol} \cdot \mathrm{L}^{-1} \mathrm{~K}^{+} ; \mathrm{K} 1: 5 \mathrm{mmol} \cdot \mathrm{L}^{-1} \mathrm{~K}^{+}$; and $\mathrm{K} 2: 20 \mathrm{mmol} \cdot \mathrm{L}^{-1} \mathrm{~K}{ }^{+}$ (control). Data are means $\pm \mathrm{SD}(n=3)$. Treatments with different letters $(\mathrm{a}, \mathrm{b}$, and c) are significantly different at $P<0.05$ level.

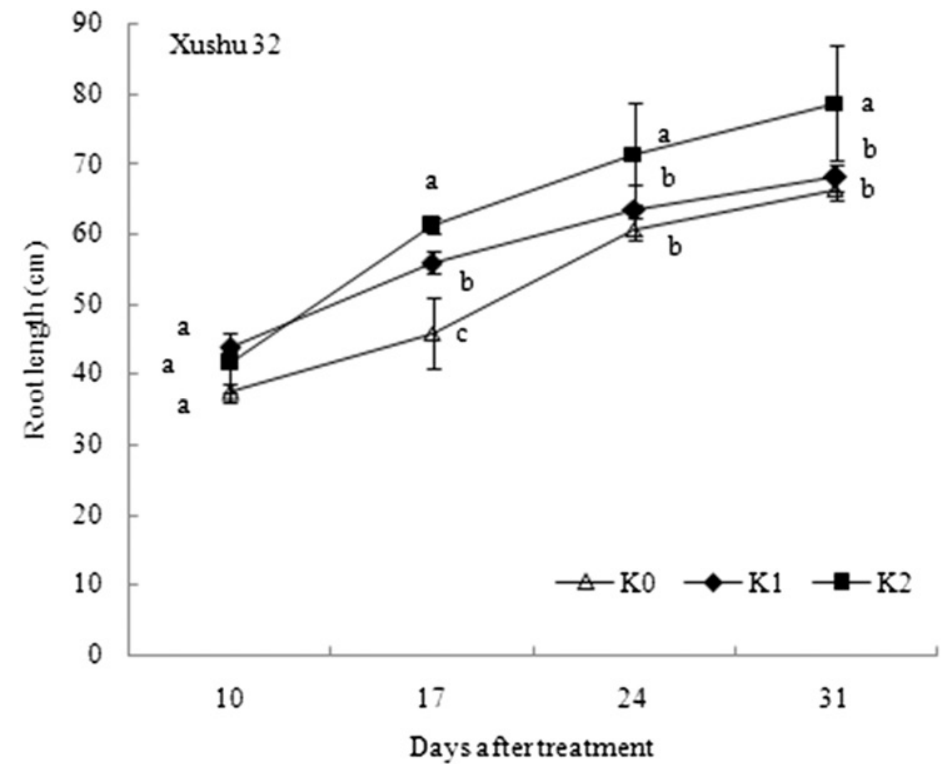

Ningzishu 1

Fig. 4. Effects of potassium deficiency on the root length of two sweetpotato varieties. $\mathrm{K} 0: 0 \mathrm{mmol} \cdot \mathrm{L}^{-1} \mathrm{~K}^{+} ; \mathrm{K} 1: 5 \mathrm{mmol} \cdot \mathrm{L}^{-1} \mathrm{~K}^{+}$; and $\mathrm{K} 2: 20 \mathrm{mmol} \cdot \mathrm{L}^{-1} \mathrm{~K}^{+}$(control). Data are means \pm SD $(n=3)$. Treatments with different letters (a,b, and c) are significantly different at $P<0.05$ level.

those in 'Xushu 32' at 10 DAT, respectively, whereas this was reversed at $31 \mathrm{DAT}$.

Transpiration rate. The changes in $T_{\mathrm{r}}$ in the two cultivars are shown in Fig. 9. The $\mathrm{K}^{+}$ deficiency caused $T_{\mathrm{r}}$ to significantly decrease in the two cultivars. At 31 DAT, the $T_{\mathrm{r}}$ of K0 and $\mathrm{K} 1$ had decreased by $42.7 \%$ and $22.9 \%$ when compared with K2 in 'Xushu 32', respectively; this change was lower than that in 'Ningzishu 1' $(66.0 \%$ and $39.4 \%$ decrease, respectively). At $31 \mathrm{DAT}$, relative to 10 DAT, the reductions in $T_{\mathrm{r}}$ were $54.6 \%$, $42.7 \%$, and $40.7 \%$ for $\mathrm{K} 0, \mathrm{~K} 1$, and $\mathrm{K} 2$ in 'Xushu 32', respectively, which were lower than the corresponding reductions of $88.7 \%$, $80.3 \%$, and $63.1 \%$ in 'Ningzishu 1 '.

Intercellular $\mathrm{CO}_{2}$ concentration. The variations of $C_{\mathrm{i}}$ of the two cultivars were inconsistent (Fig. 10). The $\mathrm{K}^{+}$deficiency caused the $C_{\mathrm{i}}$ of 'Xushu 32' to decrease at 17 DAT after treatment, after which it exceeded the control (K2). Nevertheless, no significant differences were found among three treatment levels during the experimental period. Although the $C_{\mathrm{i}}$ of $\mathrm{K} 1$ in 'Ningzishu 1' remained below that of $\mathrm{K} 2$, the $C_{\mathrm{i}}$ in $\mathrm{K} 0$ decreased linearly. At 31 DAT, the $C_{\mathrm{i}}$ in $\mathrm{K} 1$ decreased by $11.0 \%$ compared with that of $\mathrm{K} 2$, whereas the decrease in $\mathrm{K} 0$ was $36.2 \%$ and significant.

\section{Effects of $\mathrm{K}^{+}$deficiency on chlorophyll fluorescence parameters}

The chlorophyll fluorescence parameters of the two cultivars in different $\mathrm{K}^{+}$levels at 24 DAT are shown in Table 2. For 'Ningzishu 1', the $F_{0}$ was significantly increased, whereas the $F_{\mathrm{v}} / F_{\mathrm{m}}$ and $q_{\mathrm{P}}$ of the K0 treatment were significantly decreased comparing with those of $\mathrm{K} 2$, respectively. These decreases were also showed in $\mathrm{K} 1$, but no significant difference in $\mathrm{K} 0$ and $\mathrm{K} 2$. The variations of $F_{0}, F_{\mathrm{v}} / F_{\mathrm{m}}$, and $q_{\mathrm{P}}$ in $\mathrm{K} 0$ and $\mathrm{K} 1$ of 'Xushu 32' were similar to those of 'Ningzishu 1', but no significant difference was revealed among the $\mathrm{K}^{+}$treatment levels. The $q_{\mathrm{N}}$ of 'Ningzishu 1' showed an increasing response trend with $\mathrm{K}^{+}$level reduction, but no significant difference were detected among the three $\mathrm{K}^{+}$ levels, which was similar to 'Xushu 32'.

\section{Discussion}

Plant growth and physiological response to $\mathrm{K}^{+}$deficiency. Plants require $\mathrm{K}^{+}$in a larger 

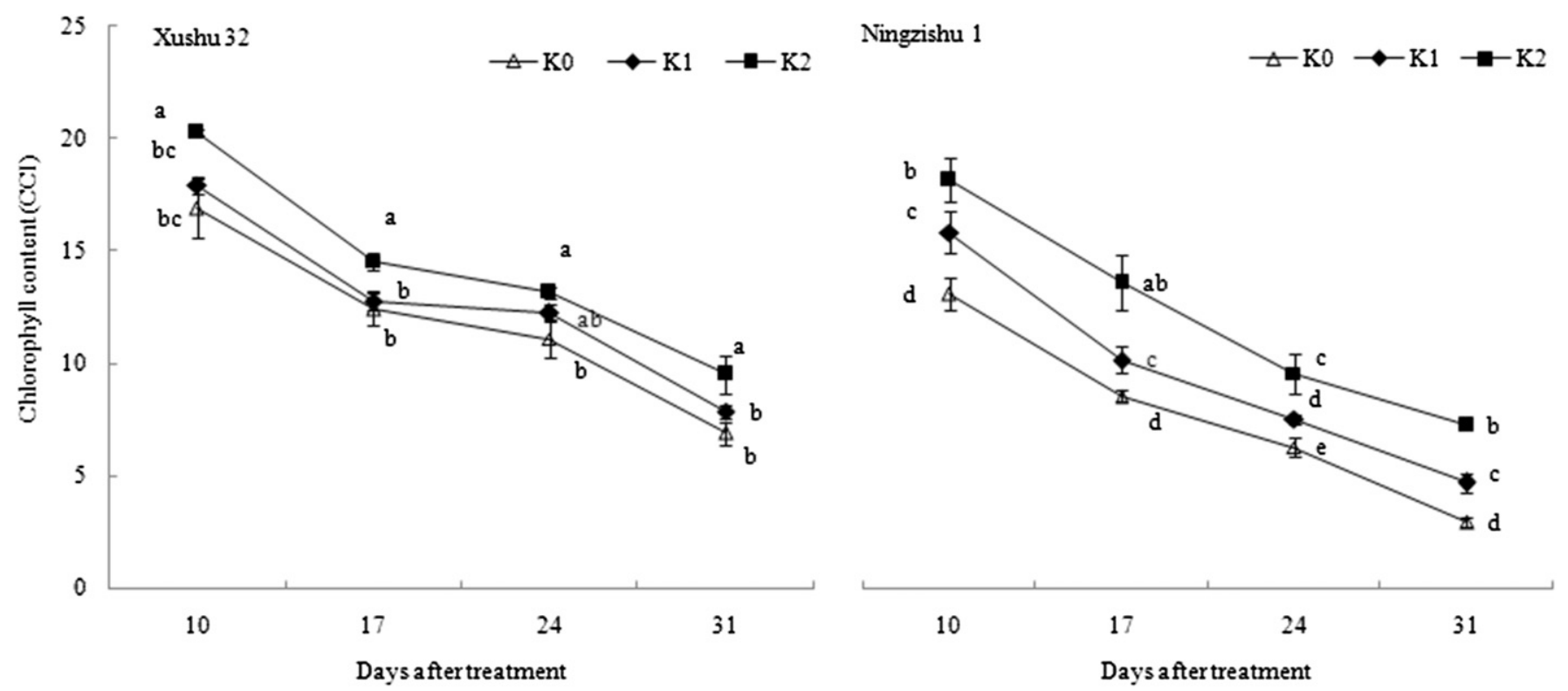

Fig. 5. Effects of potassium deficiency on the chlorophyll content $(\mathrm{CCI})$ of two sweetpotato varieties. $\mathrm{K} 0$ : $0 \mathrm{mmol} \cdot \mathrm{L}^{-1} \mathrm{~K}^{+}$; $\mathrm{K} 1: 5 \mathrm{mmol} \cdot \mathrm{L}^{-1} \mathrm{~K}{ }^{+}$; and $\mathrm{K} 2: 20 \mathrm{mmol} \cdot \mathrm{L}^{-1} \mathrm{~K}^{+}$(control). Data are means $\pm \mathrm{SD}(n=3)$. Treatments with different letters $(\mathrm{a}, \mathrm{b}$, and $\mathrm{c})$ are significantly different at $P<0.05$ level.
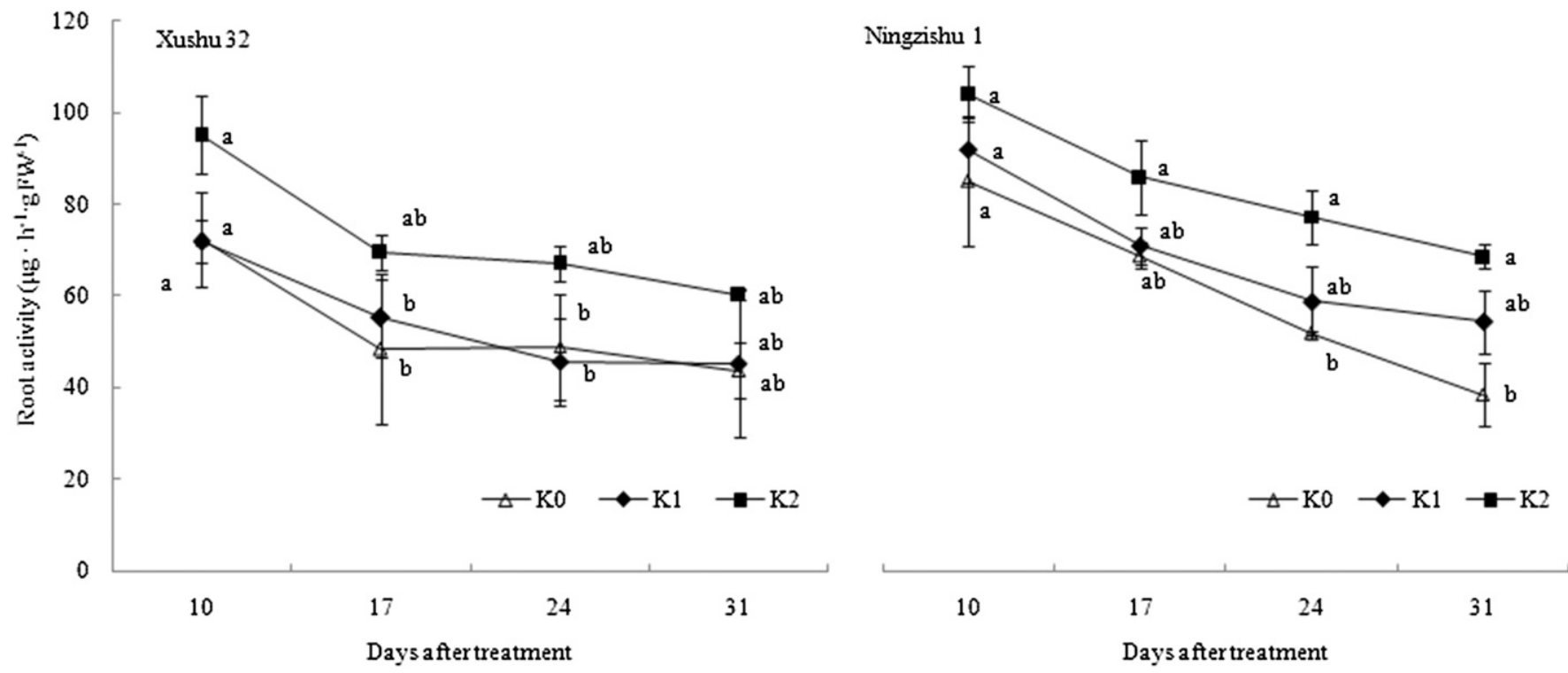

Fig. 6. Effects of potassium deficiency on the root activity of two sweetpotato varieties. $\mathrm{K} 0: 0 \mathrm{mmol} \cdot \mathrm{L}^{-1} \mathrm{~K}^{+} ; \mathrm{K} 1: 5 \mathrm{mmol} \cdot \mathrm{L}^{-1} \mathrm{~K}^{+}$; and $\mathrm{K} 2: 20 \mathrm{mmol} \cdot \mathrm{L}^{-1} \mathrm{~K}^{+}$(control). Data are means \pm SD $(n=3)$. Treatments with different letters $(\mathrm{a}, \mathrm{b}$, and $\mathrm{c})$ are significantly different at $P<0.05$ level.

amount than any other mineral element except for $\mathrm{N}$, and $\mathrm{K}^{+}$is a nutrient that often affects crop growth, yields, and quality (Jin et al., 2011). Preferable root morphology and high root activity are the prerequisites to uptake and utilization efficient of $\mathrm{K}^{+}$in plants and these are also the typical characteristics of K-efficient crop varieties (Den Herder et al., 2010). The results of this study showed that the low-K-tolerant variety, 'Xushu 32', maintained greater root lengths in the three treatment levels than 'Ningzishu 1' (Fig. 4), which led to its greater root dry weight and higher root/shoot ratio (Table 1). Hence, the 'Xushu 32' could maintain high root activities in $\mathrm{K}^{+}$deficiency conditions (Fig. 6). By contrast, the shorter root and weaker root activities in 'Ningzishu 1' seedlings probably led to less underground assimilation, and thus finally to a lowered root/shoot ratio in $\mathrm{K}^{+}$ deficiency stress. These results suggest that $\mathrm{K}^{+}$deficiency strongly inhibit plant dry weight production, and decreases the root/ shoot ratio in a sweetpotato variety sensitive to $\mathrm{K}^{+}$deficiency. These findings are similar to the results from the field experiment and sand culture experiment (Tang et al., 2015), suggesting that $\mathrm{K}^{+}$deficiency depresses considerable translocation of the assimilation product from leaves to root in the sweetpotato.

Chlorophyll is an important index reflecting crop senescence and photosynthetic capacity. Potassium deficiency restrains the synthesization of chlorophyll ( $\mathrm{Lu}$ et al.,
2016). In this study, the CCI of the two sweetpotato cultivars were reduced, especially in 'Ningzishu 1' in the $\mathrm{K}^{+}$deficiency condition (Fig. 5) which may be associated with the decreased $P_{\mathrm{n}}$ (Fig. 7). The photoassimilate accumulation reduction caused by $P_{\mathrm{n}}$ decrease probably resulted in less green leaves and a lower shoot dry weight (Table 1). As a whole, the decreases in dry weight, shoot length, CCI, and root activity of the each $\mathrm{K}^{+}$deficiency level in 'Xushu 32' were all lower than those of 'Ningzishu 1', and the growth of the 'Ningzishu 1' were more restricted, showing 'Xushu 32' had more tolerance to $\mathrm{K}^{+}$deficiency.

However, the root activity, CCI, and photosynthesis of the two cultivars also 

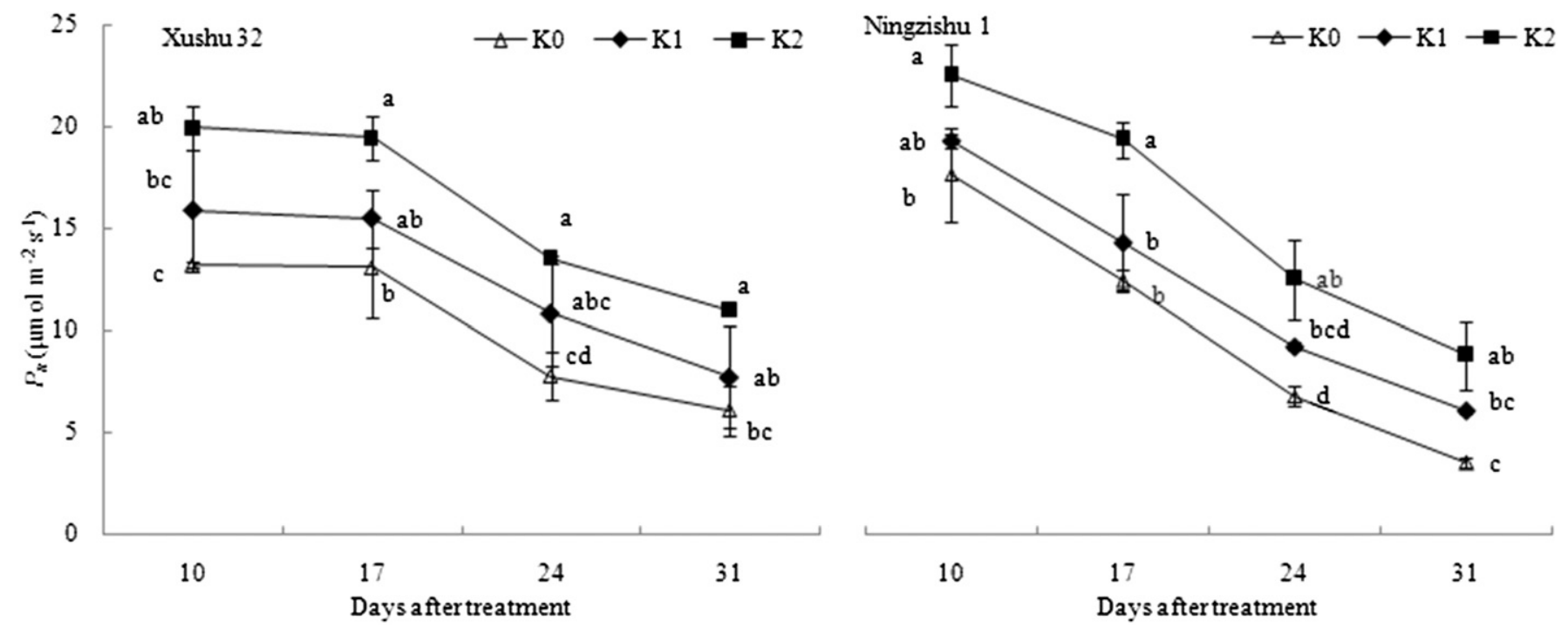

Fig. 7. Effects of potassium deficiency on the net photosynthetic rate $\left(P_{\mathrm{n}}\right)$ of two sweetpotato varieties. $\mathrm{K} 0: 0 \mathrm{mmol} \cdot \mathrm{L}^{-1} \mathrm{~K}^{+}$; K1: $5 \mathrm{mmol} \cdot \mathrm{L}^{-1} \mathrm{~K}^{+}$; and $\mathrm{K} 2: 20 \mathrm{mmol} \cdot \mathrm{L}^{-1} \mathrm{~K}^{+}$(control). Data are means $\pm \mathrm{SD}(n=3)$. Treatments with different letters $(\mathrm{a}, \mathrm{b}$, and $\mathrm{c})$ are significantly different at $P<0.05$ level.
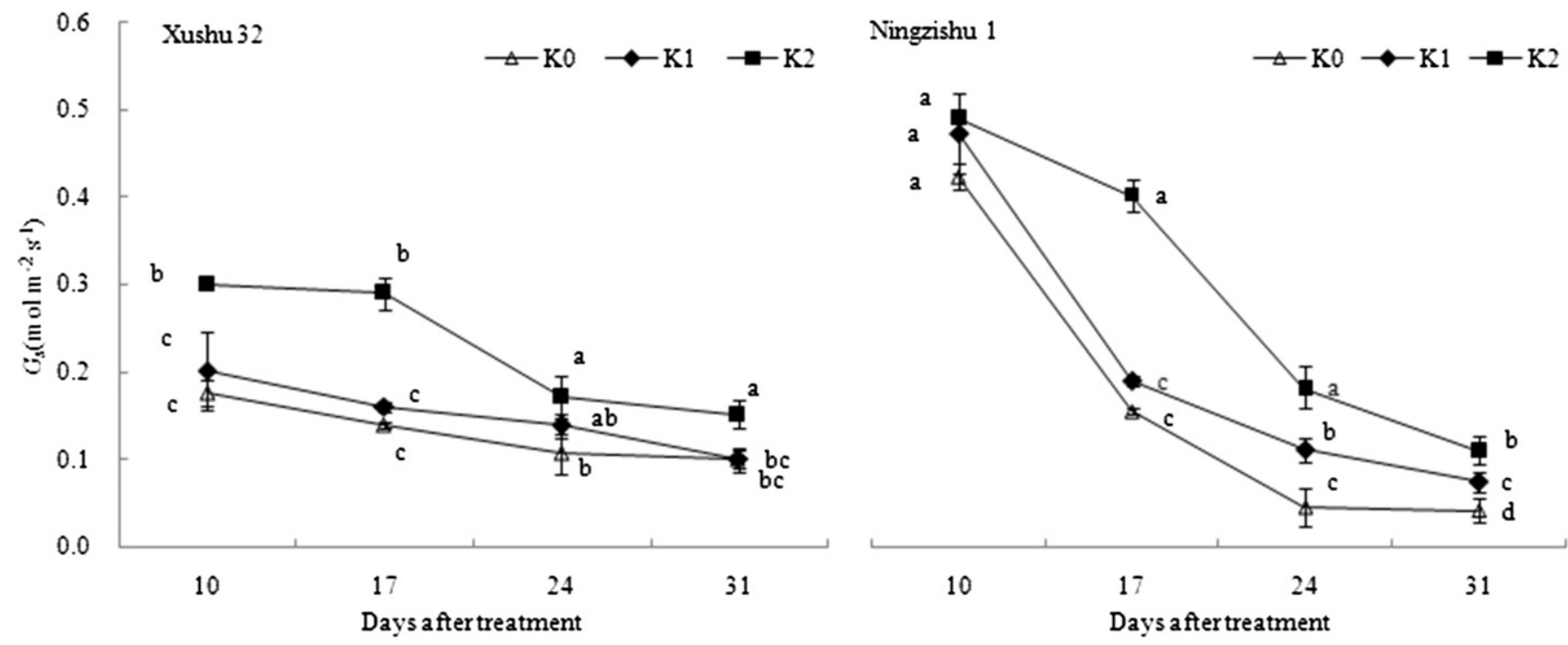

Fig. 8. Effects of potassium deficiency on the stomatal conductance $\left(g_{\mathrm{S}}\right)$ of two sweetpotato varieties. $\mathrm{K} 0: 0 \mathrm{mmol} \cdot \mathrm{L}^{-1} \mathrm{~K}^{+} ; \mathrm{K} 1: 5 \mathrm{mmol} \cdot \mathrm{L}^{-1} \mathrm{~K}^{+}$; and $\mathrm{K} 2: 20 \mathrm{mmol} \cdot \mathrm{L}^{-1} \mathrm{~K}^{+}$(control). Data are means $\pm \mathrm{SD}(n=3)$. Treatments with different letters $(\mathrm{a}, \mathrm{b}$, and $\mathrm{c})$ are significantly different at $P<0.05$ level.

showed decreases in the control condition in this study. These plants also showed premature aging in the later stage of the experiment. We presumed the reason was that the hydroponic culture condition has nutrition limitation, which is difficult to provide enough nutrition for the fast growing plants. The phenomenon was also showed in other hydroponic experiments (Peng et al., 2006; Wang et al., 2015b). It indicates that nutrient solution concentration or quantity should be adjusted with the growth of plants to ensure sufficient nutrients in hydroponic experiments. But on the other side, the hydroponic condition with controllable nutrient elements is beneficial to obtain typical symptoms of sweetpotato in $\mathrm{K}^{+}$deficiency stress instead of a soil substrate.

Photosynthesis response to $\mathrm{K}^{+}$deficiency. Potassium is an important element for photosynthetic metabolism that requires high concentrations (Marschner, 2011). In this study, as the $\mathrm{K}^{+}$supply was reduced, the $P_{\mathrm{n}}$ (Fig. 7), $g_{\mathrm{S}}$ (Fig. 8), and $T_{\mathrm{r}}$ (Fig. 9) of the two varieties were also reduced, in a pattern similar to previous studies done on other crops (Jin et al., 2011; Wang et al., 2015b). Previous studies have found that a decrease of $P_{\mathrm{n}}$ attribute to stomatal limitation when $C_{\mathrm{i}}$ and $g_{\mathrm{S}}$ declined, whereas it is attributable to nonstomatal limitation (a larger mesophyll resistance, a lower capacity of the $\mathrm{CO}_{2}$ fixation cycle, or both) when $C_{\mathrm{i}}$ increased and $g_{\mathrm{S}}$ decreased (Bednarz et al., 1998; Gerardeaux et al., 2009; Xu, 1995). In view of the reductions of $g_{\mathrm{S}}$ and $C_{\mathrm{i}}$, the main reason for the decrease of $P_{\mathrm{n}}$ in 'Ningzishu 1' should be the stomatal limitation factor in the study. However, in 'Xushu 32', the $C_{\mathrm{i}}$ showed decline first and then increase in $\mathrm{K}^{+}$deficiency, with a gradually decrease in $g_{\mathrm{S}}$. This performance was inconsistent with other published reports (Bednarz et al., 1998; Wang et al., 2015b). We suppose that the decreases of $P_{\mathrm{n}}$ in $\mathrm{K}^{+}$deficiency in 'Xushu 32' were probably caused by the common effects of stomatal and nonstomatal factors. However, the changes of $C_{\mathrm{i}}$ in 'Xushu 32' were nonsignificant and were generally steady during the experimental period. In addition, other photosynthesis traits in 'Xushu 32' were also changed less than those of 'Ningzishu 1', in conditions of $\mathrm{K}^{+}$ deficiency. These findings indicate that 'Xushu 32' could maintain relatively higher photosynthetic capacity than 'Ningzishu 1', which might be a direct physiological basis of the low-K-tolerant cultivar to maintain a better growth status.

Chlorophyll fluorescence parameters response to $K^{+}$deficiency. The changes of 

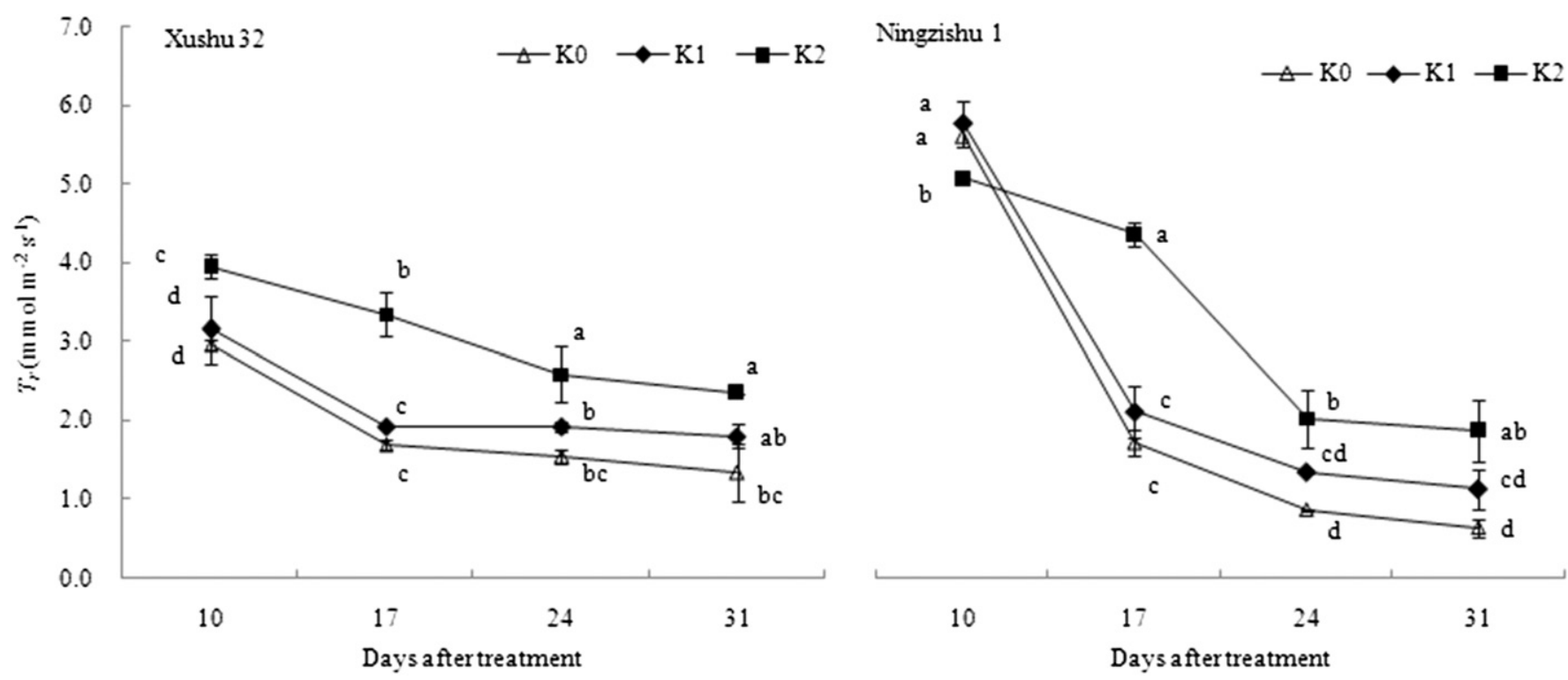

Fig. 9. Effects of potassium deficiency on the transpiration rate $\left(T_{\mathrm{r}}\right)$ of two sweetpotato varieties. $\mathrm{K} 0: 0 \mathrm{mmol} \cdot \mathrm{L}^{-1} \mathrm{~K}^{+} ; \mathrm{K} 1: 5 \mathrm{mmol} \cdot \mathrm{L}^{-1} \mathrm{~K}^{+}$; and $\mathrm{K} 2: 20 \mathrm{mmol} \cdot \mathrm{L}^{-1} \mathrm{~K}^{+}$ (control). Data are means \pm SD $(n=3)$. Treatments with different letters (a, b, and c) are significantly different at $P<0.05$ level.
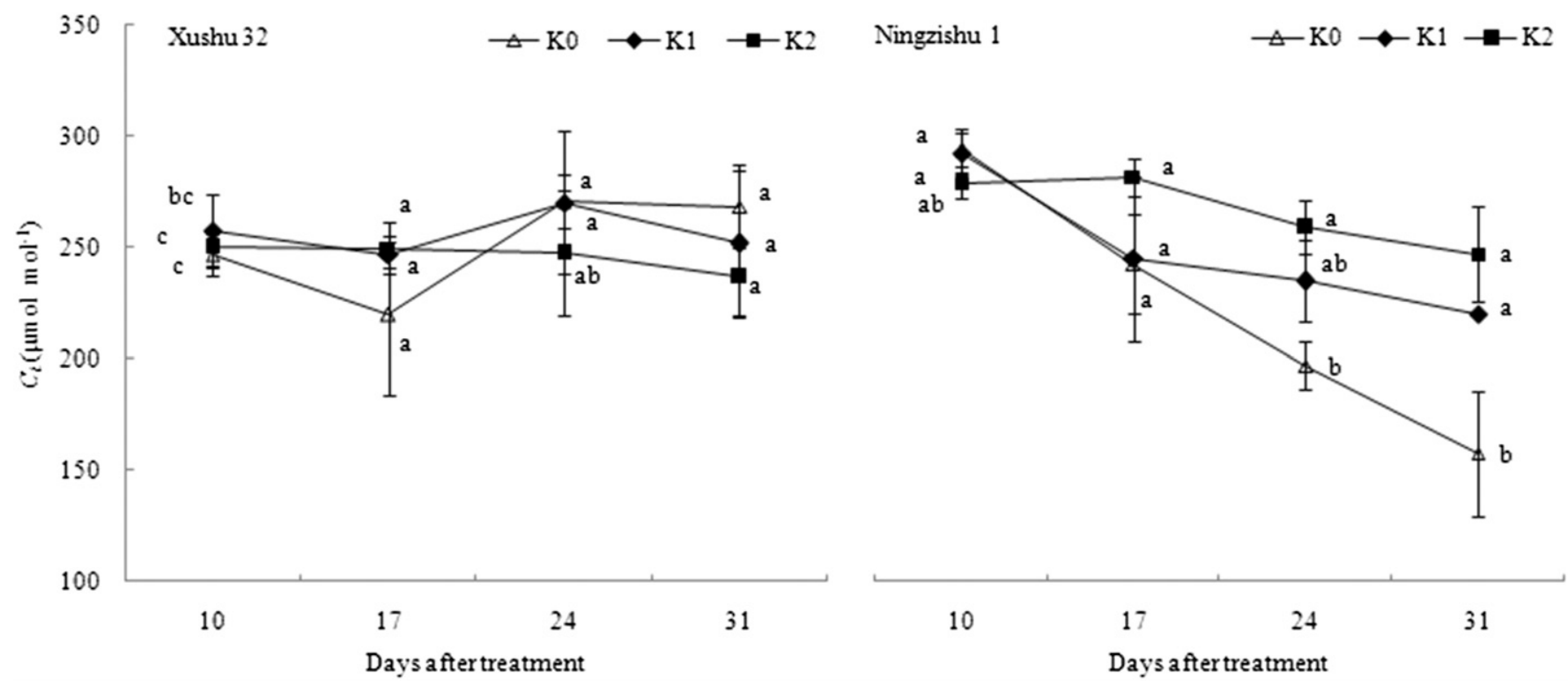

Fig. 10. Effects of potassium deficiency on the intercellular $\mathrm{CO}_{2}$ concentration $\left(C_{\mathrm{i}}\right)$ of two sweetpotato varieties. $\mathrm{K} 0: 0 \mathrm{mmol} \cdot \mathrm{L}^{-1} \mathrm{~K}^{+} ; \mathrm{K} 1: 5 \mathrm{mmol} \cdot \mathrm{L}^{-1} \mathrm{~K}^{+}$; and $\mathrm{K} 2: 20 \mathrm{mmol} \cdot \mathrm{L}^{-1} \mathrm{~K}^{+}$(control). Data are means $\pm \mathrm{SD}(n=3)$. Treatments with different letters $(\mathrm{a}, \mathrm{b}$, and $\mathrm{c})$ are significantly different at $P<0.05$ level.

Table 2. Effects of potassium deficiency on the chlorophyll fluorescence parameters of two sweetpotato varieties.

\begin{tabular}{lccccrrr}
\hline Chlorophyll fluorescence & \multicolumn{3}{c}{ Xushu 32 } & & \multicolumn{2}{c}{ Ningzishu 1 } \\
\cline { 2 - 3 } \cline { 6 - 7 } parameters & K0 & K1 & K2 & & K0 & K1 \\
\hline$F_{0}$ & $599.1 \pm 29.6 \mathrm{abc}^{2}$ & $572.2 \pm 14.2 \mathrm{bc}$ & $511.6 \pm 5.2 \mathrm{c}$ & & $671.8 \pm 66.2 \mathrm{a}$ & $650.6 \pm 13.3 \mathrm{ab}$ & $566.0 \pm 38.6 \mathrm{bc}$ \\
$F_{\mathrm{m}}$ & $1,535.5 \pm 354.9 \mathrm{a}$ & $1,646.5 \pm 13.3 \mathrm{a}$ & $1,885.2 \pm 84.0 \mathrm{a}$ & & $1,596.4 \pm 277.3 \mathrm{a}$ & $1,640.3 \pm 306.8 \mathrm{a}$ & $2,098.7 \pm 158.8 \mathrm{a}$ \\
$F_{\mathrm{v}} / F_{\mathrm{m}}$ & $0.597 \pm 0.112 \mathrm{ab}$ & $0.641 \pm 0.020 \mathrm{ab}$ & $0.729 \pm 0.019 \mathrm{a}$ & & $0.570 \pm 0.033 \mathrm{~b}$ & $0.632 \pm 0.105 \mathrm{ab}$ & $0.730 \pm 0.013 \mathrm{a}$ \\
$q_{\mathrm{P}}$ & $0.225 \pm 0.023 \mathrm{ab}$ & $0.231 \pm 0.037 \mathrm{ab}$ & $0.265 \pm 0.039 \mathrm{a}$ & & $0.173 \pm 0.016 \mathrm{~b}$ & $0.200 \pm 0.007 \mathrm{ab}$ & $0.239 \pm 0.007 \mathrm{a}$ \\
$q_{\mathrm{N}}$ & $0.929 \pm 0.031 \mathrm{a}$ & $0.935 \pm 0.015 \mathrm{a}$ & $0.914 \pm 0.041 \mathrm{a}$ & & $0.947 \pm 0.024 \mathrm{a}$ & $0.943 \pm 0.012 \mathrm{a}$ & $0.919 \pm 0.010 \mathrm{a}$ \\
\hline
\end{tabular}

$\mathrm{K} 0=0 \mathrm{mmol} \cdot \mathrm{L}^{-1} \mathrm{~K}^{+} ; \mathrm{K} 1=5 \mathrm{mmol} \cdot \mathrm{L}^{-1} \mathrm{~K}^{+} ; \mathrm{K} 2=20 \mathrm{mmol} \cdot \mathrm{L}^{-1} \mathrm{~K}^{+}($control $) ; F_{0}=$ the minimal fluorescence; $F_{\mathrm{m}}=$ the maximal fluorescence; $F_{\mathrm{v}} / F_{\mathrm{m}}=$ the maximum quantum efficiency of PSII photochemistry; $q_{\mathrm{P}}=$ photochemical quenching; $q_{\mathrm{N}}=$ nonphotochemical quenching.

${ }^{\mathrm{z}}$ Means within same column followed by different letters $(\mathrm{a}, \mathrm{b}$, and $\mathrm{c})$ are significantly different between $\mathrm{K}$ treatments of the two genotypes $(P<0.05)$. Data are means \pm SD $(n=3)$.

chlorophyll fluorescence parameters are helpful to understand the photosynthetic light absorption, distribution, and dissipation in the photosynthesis process, which can reflect the stress of plants (Maxwell and Johnson, 2000; Morant-Manceau et al., 2004). The increase of $F_{0}$ indicates a reversible inactivation or irreversible damage of the reaction centers of PSII, and the decrease of $F_{\mathrm{v}} / F_{\mathrm{m}}$ indicates the primary conversion of light energy of PSII was reduced (Lichtenthaler and Babani, 2004). The significant changes 
of $F_{0}$ and $F_{\mathrm{v}} / F_{\mathrm{m}}$ in 'Ningzishu 1' in the extreme $\mathrm{K}^{+}$deficiency condition $(\mathrm{K} 0)(\mathrm{Ta}-$ ble 2) suggests that the structure and function of the reaction center were damaged and destroyed in a certain degree. These findings of sweetpotato are similar to those of other plants (Li et al., 2011; Wang et al., 2015b). Also, these variations were related to the decline of $P_{\mathrm{n}}$ (Fig. 7). The main reason of $F_{\mathrm{v}} / F_{\mathrm{m}}$ decrease of 'Ningzishu 1' should be the significant increase of $F_{0}$.

The $q_{\mathrm{P}}$ of the two cultivars showed an decreasing trend in response to $\mathrm{K}^{+}$level reduction, significant difference was showed in $\mathrm{K} 0$ condition compared with $\mathrm{K} 2$ in 'Ningzishu 1'. The decrease of $q_{\mathrm{P}}$ indicates that the opening proportion of PSII reaction centers and the electrons involved in $\mathrm{CO}_{2}$ fixation were decreased, and these decreases will weaken the photosynthetic electron transport capacity, block the dark reaction of leaf, and decrease the $P_{\mathrm{n}}$ (Dannehl et al., 1996). In this study, it can be found that the decreased $q_{\mathrm{P}}$ is consistent with the decrease of $P_{\mathrm{n}}$ (Fig. 7). The $q_{\mathrm{N}}$ is an important nonphotochemical quenching parameter, reflecting the changes in the plant heat dissipation capacity (Müller et al., 2001). The $q_{\mathrm{N}}$ of the two cultivars revealed particular increases in the tested conditions of $\mathrm{K}^{+}$deficiency. This result suggests that the leaves improve heat dissipation to consume exceed excitation energy through nonphotochemical quenching pathway, it may be a way to adapt to $\mathrm{K}^{+}$deficiency stress.

Generally, all the chlorophyll fluorescence parameters in 'Xushu 32' were less affected comparing with 'Ningzishu 1', indicating that the PSII reaction centers were less damaged. A higher actual photochemical efficiency was maintained in low-K-tolerant sweetpotato variety in $\mathrm{K}^{+}$deficiency stress.

\section{Conclusion}

Compared with 'Ningzishu 1' (sensitive to $\mathrm{K}^{+}$deficiency), the dry weight, number of leaves, root length, and CCI of 'Xushu 32' (tolerance to $\mathrm{K}^{+}$deficiency) were less varied with the $\mathrm{K}^{+}$deficiency time extending, which indicated tolerance to $\mathrm{K}^{+}$deficiency cultivar could maintain higher growth. In addition, only in K0 condition were the $P_{\mathrm{n}}, g_{\mathrm{S}}$, and $T_{\mathrm{r}}$ of 'Xushu 32' reduced significantly, and the decreases were all less pronounced than those of 'Ningzishu 1' in both $\mathrm{K} 0$ and $\mathrm{K} 1$ treatments. On the 24 DAT, all the chlorophyll fluorescence parameters in 'Xushu 32' were slight and not significantly changed, whereas for 'Ningzishu 1', the $F_{0}$ was significantly increased, and the $F_{\mathrm{v}} / F_{\mathrm{m}}$ and $q_{\mathrm{P}}$ were significantly decreased. These results indicated that the tolerance to $\mathrm{K}^{+}$deficiency cultivar could maintain a better growth state in $\mathrm{K}^{+}$ deficiency stress, which may be mainly because of a lighter affected physiological role and photosynthesis, and a less damaged structure and function of PSII reaction center.

\section{Literature Cited}

Bednarz, C.W., D.M. Oosterhuis, and R.D. Evans. 1998. Leaf photosynthesis and carbon isotope discrimination of cotton in response to potassium deficiency. Environ. Exp. Bot. 39:131-139.

Bednarz, C.W. and D.M. Oosterhuis. 1999. Physiological changes associated with potassium deficiency in cotton. J. Plant Nutr. 22:303-313.

Bürling, K., M. Hunsche, and G. Noga. 2011. Use of blue-green and chlorophyll fluorescence measurements for differentiation between nitrogen deficiency and pathogen infection in winter wheat. J. Plant. Physio. 168:1641-1648.

Constantin, R.J., L.G. Jones, and T.P. Hernandez. 1977. Effects of potassium and phosphorous fertilization on quality of sweetpotatoes. J. Amer. Soc. Hort. Sci. 102:779-781.

Coskun, D., D.T. Britto, and H.J. Kronzucker. 2014. The physiology of channel-mediated $\mathrm{K}^{+}$ acquisition in roots of higher plants. Physiol. Plant. 151:305-312.

Den Herder, G., G. Van Isterdael, T. Beeckman, and I. De Smet. 2010. The roots of a new green revolution. Trends Plant Sci. 15:600-607.

Dannehl, H., H. Wietoska, H. Heckmann, and D. Godde. 1996. Changes in D1-protein turnover and recovery of photosystem II activity precede accumulation of chlorophyll in plants after release from mineral stress. Planta 199:34 42.

FAO (Food and Agriculture Organization). 2011. Food and agricultural commodities production. Food and Agriculture Organization of the United Nations (FAO), Rome.

Gajanayake, B., K.R. Reddy, M.W. Shankle, and R.A. Arancibia. 2014. Growth, developmental, and physiological responses of two sweetpotato (Ipomoea batatas L. [Lam]) cultivars to early season soil moisture deficit. Sci. Hort. 168:218-228.

George, M.S., G.Q. Lu, and W.J. Zhou. 2002. Genotypic variation for potassium uptake and utilization efficiency in sweetpotato (Ipomoea batatas L.). Field Crops Res. 77:7-15.

Gerardeaux, E., E. Saur, J. Constantin, A. Porté, and L. Jordan-Meille. 2009. Effect of carbon assimilation on dry weight production and partitioning during vegetative growth. Plant Soil 324:329-343.

He, P., J.Y. Jin, W.J. Li, H.L. Liu, S.W. Huang, X.F. Wang, L.C. Wang, and J.G. Xie. 2004. Comparison of potassium absorption, yield and quality between high-oil and common corn affected by potassium application. Plant Nutr. Fertilizer Sci. 11:620-626.

Hijmans, R.J., L. Huaccho, and D. Zhang. 2001. Description and analysis of a geo-referenced database of the global distribution of sweetpotato area. International Conference on Sweetpotato. Food and Health for the Future 583 41-49.

Høgh-Jensen, H. 2003. The effect of potassium deficiency on growth and $\mathrm{N}_{2}$-fixation in Trifolium repens. Physiol. Plant. 119:440-449.

Jin, J. 2012. Changes in the efficiency of fertiliser use in China. J. Sci. Food Agr. 92:1006-1009.

Jin, S.H., J.Q. Huang, X.Q. Li, B.S. Zheng, J.S. Wu, Z.J. Wang, G.H. Liu, and M. Chen. 2011. Effects of potassium supply on limitations of photosynthesis by mesophyll diffusion conductance in Carya cathayensis. Tree Physiol. 31:1142-1151.

Kanai, S., R.E. Moghaieb, H.A. El-Shemy, R. Panigrahi, P.K. Mohapatra, J. Ito, N.T. Nguyen, H. Saneoka, and K. Fujita. 2011. Potassium deficiency affects water status and photosynthetic rate of the vegetative sink in green house tomato prior to its effects on source activity. Plant Sci. 180:368-374.

Karam, F., Y. Rouphael, R. Lahoud, J. Breidi, and G. Colla. 2009. Influence of genotypes and potassium application rates on yield and potassium use efficiency of potato. J. Agron. 8:27-32. Lichtenthaler, H.K. and F. Babani. 2004. Light adaptation and senescence of the photosynthetic apparatus. Changes in pigment composition, chlorophyll fluorescence parameters and photosynthetic activity, p. 713-736. In: G. Papageoriou and Govindjee (eds.). Chlorophyll fluorescence: A signature of photosynthesis. Springer, The Netherlands.

Li, X.T., P. Cao, X.G. Wang, M.J. Cao, and H.Q. Yu. 2011. Comparison of gas exchange and chlorophyll fluorescence of low-potassiumtolerant and-sensitive soybean [Glycine max (L.) Merr.] cultivars under low-potassium condition. Photosynthetica 49:633-636.

Lu, Z.F., T. Ren, J.W. Lu, X.K. Li, R.H. Cong, Y.H. Pan, and K.X. Li. 2016. Main factors and mechanism leading to the decrease of photosynthetic efficiency of oilseed rape exposure to potassium deficiency. J. Plant Nutr. Fert. 22:122-131. (in Chinese).

Marschner, P. 2011. Marschner's Mineral Nutrition of Higher Plants. Academic Press, Salt Lake, UT.

Maxwell, K. and G.N. Johnson. 2000. Chlorophyll fluorescence - a practical guide. J. Exp. Bot. 51:659-668.

Mohotti, A.J. and D.W. Lawlor. 2002. Diurnal variation of photosynthesis and photoinhibition in tea: Effects of irradiance and nitrogen supply during growth in the field. J. Exp. Bot. 53:313322.

Morant-Manceau, A., E. Pradier, and G. Tremblin. 2004. Osmotic adjustment, gas exchanges and chlorophyll fluorescence of a hexaploid triticale and its parental species under salt stress. J. Plant Physiol. 161:25-33.

Müller, P., X.P. Li, and K.K. Niyogi. 2001. Nonphotochemical quenching. A response to excess light energy. Plant Physiol. 125:1558-1566.

Ning, Y.W., H.B. Ma, X.J. Xu, J.D. Wang, H. Zhang, J.P. Xu, J. Chen, and Y.C. Zhang. 2013. Effects of deficiency of N, P, or K on growth traits and nutrient uptakes of sweetpotato at early growing stage. Sci. Agr. Sin. 46:486-495. (in Chinese).

Peng, H.H., X.Y. Weng, H.X. Xu, S.Q. Jiang, and J.W. Sunday. 2006. Effects of potassium deficiency on photosynthesis and photo-protection mechanisms in rice plants. Chin. J. Rice Sci. 20:621-625. (in Chinese).

Reddy, K.R. and D. Zhao. 2005. Interactive effects of elevated $\mathrm{CO}_{2}$ and potassium deficiency on photosynthesis, growth, and biomass partitioning of cotton. Field Crops Res. 94:201-213.

Singh, B., Y. Singh, P. Imas, and J.C. Xie. 2003 Potassium nutrition of the rice-wheat cropping system. Adv. Agron. 81:203-259.

Tang, Z.H., Y.G. Zhang, M. Wei, X.G. Chen, X.M. Shi, A.J. Zhang, H.M. Li, and Y.F. Ding. 2014. Screening and evaluation indicators for low potassium-tolerant and potassium efficient sweetpotato (Ipomoea batatas L.) varieties (lines). Acta Agron. Sin. 40:542-549. (in Chinese).

Tang, Z.H., A.J. Zhang, M. Wei, X.G. Chen, Z.H. Liu, H.M. Li, and Y.F. Ding. 2015. Physiological response to potassium deficiency in three sweetpotato (Ipomoea batatas [L.] Lam.) genotypes differing in potassium utilization efficiency. Acta Physiol. Plant. 37:1-10.

Wang, J.D., H.Y. Wang, Y.C. Zhang, J.M. Zhou, and X.Q. Chen. 2015a. Intraspecific variation in potassium uptake and utilization among sweetpotato (Ipomoea batatas L.) genotypes. Field Crops Res. 170:76-82. 
Wang, N., H.B. Hua, A.E. Eneji, Z.H. Li, L.S. Duan, and X.L. Tian. 2012. Genotypic variations in photosynthetic and physiological adjustment to potassium deficiency in cotton (Gossypium hirsutum). J. Photochem. Photobiol. B 110:1-8.

Wang, Q.M., L.M. Zhang, and Z.L. Wang. 2005. Formation and thickening of tuberous roots in relation to the endogenous hormone concentrations in sweetpotato. Sci. Agr. Sin. 38:2414 2420. (in Chinese).

Wang, X.G., X.H. Zhao, C.J. Jiang, C.H. Li, S. Cong, D. Wu, Y.Q. Chen, and C.Y. Wang. 2015b. Effects of potassium deficiency on photosynthesis and photoprotection mechanisms in soybean (Glycine $\max (\mathrm{L}$.) Merr.). J. Integr. Agr. 14:856-863.
Wang, X.K., W.H. Zhang, Z.B. Hao, X.R. Li, Y.Q. Zhang, and S.M. Wang. 2006. Principles and techniques of plant physiological biochemical experiment. Higher Education Press, Beijing, China. p. 118-119. (in Chinese).

Wang, Y. and W.H. Wu. 2013. Potassium transport and signaling in higher plants. Annu. Rev. Plant Biol. 64:451-476.

Xu, D.Q. 1995. Non-uniform stomatal closure and non-stomatal limitation of photosynthesis. Plant. Physiol. Commun. 246-252. (in Chinese).

Yang, X.E., J.X. Liu, W.M. Wang, H. Li, A.C. Luo, Z.Q. Ye, and Y. Yang. 2003. Genotypic differences and some associated plant traits in potassium internal use efficiency of lowland rice (Oryza sativa L.). Nutr. Cycl. Agroecosyst. 67:273-282.
Yang, Y., D. Jiang, J. Sun, Z. Huang, and S. Jin. 2004. Effects of different magnesium nutrition levels on chlorophyll fluorescence characteristics and excitation energy dissipation in rice leaves. Plant Nutr. Fert. Sci. 11:79-86.

Zhao, D., D.M. Oosterhuis, and C.W. Bednarz. 2001. Influence of potassium deficiency on photosynthesis, chlorophyll content, and chloroplast ultrastructure of cotton plants. Photosynthetica 39:103-109.

Zhao, X.H., H.Q. Yu, J. Wen, X.G. Wang, Q. Du, J. Wang, and Q. Wang. 2016. Response of root morphology, physiology and endogenous hormones in maize (Zea mays L.) to potassium deficiency. J. Integr. Agr. 15:785794. 